\title{
UNUSUAL CASE OF A TALON CUSP ON A SUPERNUMERARY TOOTH IN ASSOCIATION WITH A HYPERDONTIA: A VIEW ON THEIR ETIOPATHOGENESIS
}

Deepa Hugar ${ }^{1}$, Sangmeshwar Sajjanshetty ${ }^{2}$, Santosh Hugar ${ }^{3}$, Sridevi Tamagond ${ }^{4}$

\section{HOW TO CITE THIS ARTICLE:}

Deepa Hugar, Sangmeshwar Sajjanshetty, Santosh Hugar, Sridevi Tamagond. "Unusual Case of A Talon Cusp On A Supernumerary Tooth In Association With A Hyperdontia: A View On Their Etiopathogenesis". Journal Of Evolution Of Medical And Dental Sciences 2013; Vol2, Issue 50, December 16; Page: 9732-9738.

\begin{abstract}
Talon cusp is an accessory cusp similar to a projection, extending from the cingulum or cemento-enamel junction to the incisal edge. It occurs on labial or palatal surfaces of primary or permanent anterior teeth in both arches. This accessory cusp can occur as an isolated entity or in association with other dental anomalies. Occurrence of a talon cusp on supernumerary teeth is rare and uncommon. This paper reports an unusual case of a talon cusp on a supernumerary tooth associated with hyperdontia.
\end{abstract}

KEY WORDS: Talon cusp, supernumerary tooth, Hyperdontia.

INTRODUCTION: Talon cups are morphologically well-delineated, accessory talon-shaped cusps, projecting from the lingual or facial surface of the crown of incisors and extending at least half the distance from the cementoenamel junction to the incisal edge ${ }^{1}$.Talon cusp can occur in maxillary or mandibular anterior teeth in both the primary and permanent dentition. This accessory cusp can occur as an isolated entity or in association with other dental anomalies. Occurrence of talon cusp on supernumerary teeth is extremely rare.

This accessory cusp shows increased predilection for males and the maxilla2, ${ }^{3}$.Reported review of literature has shown that talon cusp exhibits a prevalence of $75 \%$ in the permanent dentition compared to $25 \%$ in the primary dentition ${ }^{3}$. The prevalence of talon cusp varies considerably between different ethnic groups. It has a prevalence rate of $0.06 \%$ in Mexican, $7.7 \%$ in North Indian, $0.17 \%$ in American and $2.5 \%$ in Hungarian children ${ }^{4-7}$.

Hyperdontia is the development of an increased number of teeth and the additional teeth are termed supernumerary.Supernumerary teethis expressed by an increased number of teeth over that described by the normal dental formula I2, C1, PM2, M38. The first report of a Supernumerary tooth appeared between AD $23 \& 7^{9}$.Supernumerary teeth may vary in shape, size and structure or they can resemble the adjacent tooth ${ }^{10,11}$. They can be classified according to their position of the arch and their shape

Classification of supernumerary teeth is based on form and position ${ }^{8}$.(Table.1)

The anterior midline of the maxilla (mesiodens) is the most common site and the maxillary molar area (fourth molar or paramolar) is the second most common site.Approximately $76 \%$ to $86 \%$ of cases represent single tooth Hyperdontia ${ }^{12}$.

CASE REPORT: 12-year-old boy reported to the private dental clinicwith a complaint of poor aesthetics and an additional tooth in the upper jaw. Intraoral examination revealed no soft tissue abnormalities. Maxillary right central incisor was slightly labially positioned with midline diastemabecause of a palatally positioned supernumerary tooth. The supernumerary tooth 
resembled maxillary central incisor with a mature root and pronounced mamellons and a talon cusp on the palatal surface. The talon cusp was pyramidal in shape and extended from the cementoenamel junction to the incisal edge (Figure 3 and 4).On left side there is a presence of one extra lateral incisor exhibiting hyperdontia.

The periapical radiograph (Figure 4) showed a V-shaped radiopaque structure superimposed on the image of the involved tooth crown, with the tip of the ' $\mathrm{V}$ ' towards the incisal edge. Shallow developmental grooves were present at the junction of the talon cusp with the palatal surface of the affected tooth without any carious lesions. There is a presence of one extra Maxillary lateral incisor on left side.

DISCUSSION: Talon cusp was reported by Mitchell et al in 1892 and was given the name talon cusp by Mellor talon.

It is an accessory cusp-like structure. This anomaly varies widely in shape, size, structure, location and origin. This cusp can occur on lingual or labial surfaces of either primary or permanent anterior teeth. Occurrence of a talon cusp on the labial surface and double labial talon cusps is rare and uncommon ${ }^{13}$.Occurrence of talon cusps on supernumerary teeth is extremely rare.

Pubmed and Medline search reveals six cases of talon cusps on supernumerary permanent ${ }^{14}$, 15, 16and primary $12,15,17$ and three cases on supplemental permanent teeth ${ }^{18}$.

Histomorphometric examination has revealed that the talon cusp has normal enamel and dentin with a substantially enlarged pulp tissue, which suggests that talon tooth, may be a developmental anomaly originating in the stage of morphodifferentiation ${ }^{10}$.

Hattabet $\mathrm{al}^{2}$ categorized talon cusps into three types based on the degree of cusp formation and extension.

Type 1 - Talon additional cusp extends to at least half the distance from the cementoenamel junction and the incisal edge.

Type 2 - Semi-talon is an additional cusp extending to less than half the distance from the cementoenamel junction and the incisal edge.

Type -3- Trace talons present as enlarged or prominent cingulum.

The anomaly appears to be more frequent in Rubinstein-Taybi syndrome ${ }^{19}$, Mohr syndrome ${ }^{20}$, Sturge-Weber syndrome ${ }^{21}$ and inconti-nentia pigmenti22.Talon cusps may be of great clinical importance and early diagnosis may be critical. Small talon cusps are usually asymptomatic and need no treatment. On the other hand, large prominent cusps may cause clinical problems, including poor aesthetics, occlusal interference, and displacement of the affected tooth, carious lesions in the developmental grooves and pulpal exposure due to cuspal attrition, accidental cuspal fracture, pulpal necrosis, periapicalpathoses, periodontal pockets, tongue irritation and possibility oftemporomandibular joint pain 1 2,23,25.

The majority of cases reported in the literature indicate that talon cusp is an isolated anomaly rather than an integral part of any disorder. Talon cusp can be found in isolation or in association with other dental anomalies such as peg-shaped lateral incisors, shovel-shaped incisors, bifid cingulum, unerupted canines and the large cusp of Carabelli, dens invagi-natus, supernumeraries and complex odon-tomas 2 23, 26. 


\section{CASE REPORT}

Supernumerary teeth may occur singly, multiply, unilaterally or bilaterally in the maxilla, mandible or both.Their shape and size may resemble the group of teeth at the site where theyare found in the jaws or there may be little or no resemblance at all.The Supernumerary tooth which bears resemblance to the tooth with which it is associated is called supplementary teeth.

Causes of Supernumerary teeth.

- Proliferation of the Dental Lamina ${ }^{27-29}$

- Genetic Factors9, 29, 31-34

- Anomalous Proliferation of External Epithelial Layer of Enamel9,31-34

- Environmental Factors 27,34

- Hereditary Occurrence $27-29$

- Phylogenetic theory as regression to the Anthropoidswhere dentalformula has more teeth ${ }^{27}$

- Linked to X Chromosome ${ }^{27}$

- An Abnormal Reaction to a Local Traumatic Episode 27

- Dichotomy of Tooth Germ ${ }^{27}$

- Atavism $^{9}$

ETIOPATHOGESIS: Indeed, many of the molecular signalling pathways known to be involved in the normal development of the tooth germ can also give rise to additional teeth if inappropriately regulated.These include components of the hedgehog, FGF, Wnt, TNF and BMP Families, which provide a use full source of candidate genes that may potentially play a role in human supernumerary tooth formation 35 .

It is assumed that cranial neural crest cells emerge and go into the first branchial arch to become teeth, through mesenchymal interaction which gives rise to the position of where the teeth will be.Then through epithelial mesenchymal interactions the shape, size and contour of the individual teeth begin to take place ${ }^{36}$.

During early tooth development, growth morphogenic proteins BMP s and the FGF family mediate inductive signaling.These factors appear to be expressed at the right place and right time.BMP-2 and BMP-4 mimic the effects of the epithelium on the dental mesenchyme.They also include MSX-1 and MSX-2 which are regulatory genes.BMPs appear to act as essential inductive factors for tooth morphogenesis.

Supernumary teeth most probably result from continued proliferation of the permanent or primary dental lamina to form a third tooth germ.Most are isolated events, although some may be familial and others may be syndrome associated (Gardner's syndrome and cleidocranial dysplasia) ${ }^{37}$.

The exact etiology of Talon cusp remains unknown. It is thought to occur during morphodifferentiation stage as a result of outward folding of inner enamel epithelial cells (precursors of ameloblasts) and transient focal hyperplasia of mesenchymal dental papilla (precursors of odontoblasts) or a combination of genetic and environmental factors (multifactorial) ${ }^{2}$.

The present case shows the following features: 1. unusual occurrence of talon cusp on 


\section{CASE REPORT}

supernumerary teeth; 2.presence of one extra left lateral incisor and midline diastema. Treatment was planned for surgical extraction of the partially erupted supernumerary tooth and regular follow up followed by orthodontic correction of remaining abnormalities.

CONCLUSION: Talon cusp is an odontogenic anomaly arising during the morphodifferentiation stage of tooth development. This accessory cusp can occur on primary or permanent anterior teeth. Occurrence of talon cusp on supernumerary teeth is rare and uncommon. Presence of a prominent talon cusp may give rise to various clinical problems, necessitating immediate intervention.

\section{REFERENCES:}

1. Jowharji N, Noonansr RJ, Tylka JN. An unusual case of dental anomaly: a facial talon cusp. J Dent Child 1992; 59:156-8.

2. Hattab FN, Yassin OM, Nimri KS. Talon cusp-clinical significance and management: Case reports. Quintessence Int 1995; 26:115-120.

3. Hattab FN, Yassin OM, Al-Nimrin KS. Talon cusp in perma-nent dentition associated with other dental anomalies: Review of literature and report of seven cases. J Dent Child 1996; 63:368-76.

4. Sedano HO, et al. Clinical orodental abnormalities in Mexican children. Oral Surg Oral Med Oral Pathol 1989; 68:300-11.

5. Chawla HS, Tewari A, Gobulakrishnan NS. Talon cusp: a prevalence study. J Indian SocPedodPrev Dent 1983; 1:28-34.

6. Buenviaje TM, Rapp R. Dental anomalies in children: A clinical and radiographic survey. J Dent Child 1984; 51: 42-6.

7. MavrodiszKatalin; BudaiMária; TarjánIldikó. Prevalence of talon cusp in patients aged 7-18. FogorvosiSzemle 2003; 96:257-9.

8. White S, Pharoah M, O Connor D. Oral radiology: principles and interpretation. 2nd: Mosby St. Louis, London: 2000.

9. Srivastav P, Mesiodens with unsual morphology and multiple impacted supernumerary teeth in a non-syndromic patient Indian Journal of Dental Research 2010; 18(3):138.

10. Kalra N, Chaudhary S, Sanghi S. Nonsyndrome multiple supplemental supernumerary teeth. Journal of Indian Society of Pedodontics and Preventive Dentistry 2005; 23(1):46.

11. Yassin O, Hamori E. Characteristics, clinical Features and Treatment of Supernumerary Teeth. Journal of Clinical Pediatric Dentistry 2009; 33(3); 247-50.

12. Oral and Maxillofacial pathology, Neville Damm, Allen Bouquot, 3 rdedition. , Page. no80-81.

13. Shashikiran ND, Babaji P, Reddy VV. Double facial and lingual trace talon cusps: A case report. J Indian SocPedodPrev Dent 2005; 23:89-91

14. Rani A K, Metgud S, Yakub SS, Pai U, Toshniwal NG, Bawaskar N. Endodontic and esthetic management of maxillary lateral incisor fused to a supernumerary tooth associated with a talon cusp by using spiral computed tomography as a diagnostic aid: a case report. J Endod 2010; 36:345-9.

15. Nadkarni UM, Munshi A, Damle SG. Unusual presentation of talon cusp: two case reports. Int J Paediatr Dent 2002; 12:332-5.

16. Salama FS, Hanes CM, Hanes PJ, Ready MA. Talon cusp: a review and two case reports on supernumerary primary and permanent teeth. J Dent Child 1990; 57:147-49. 
17. TopaloğluAk A, Eden E, Ertuğrul F, Sütekin E. Supernumerary primary tooth with facial and palatal talon cusps: a case report. J Dent Child (Chic) 2008; 75:309-12.

18. Lee CK, King NM, Lo EC, Cho SY. Management of supplemental permanent maxillary lateral incisors in association with talon cusp on the primary predecessors: a report of 3 cases. J Dent Child (Chic) 2008; 75:59-63.

19. Subba Reddy VV, Mehta DS. Talon cusp in a primary lateral incisor: report of a case. JIndian SocPedodPrev Dent 1989; 7:20-2.

20. Gardner DG, Girgis SS. Talon cusps: A dental anomaly in the Rubinstein-Taybi syndrome. Oral Surg 1979; 47:519-21.

21. Galdstean E, Medina JL. Mohr syndrome or oro-facial-digital II: Report of two cases. J Am Dent Assoc 1974; 89:377-82.

22. Chen RJ, Chen HS. Talon cusp in primary dentition. Oral Surg Oral Med Oral Pathol 1986; 62:67-72.

23. Tsutsumi T, Oguchi H. Labial talon cusp in a child with in-continentiapigmentiachromians: Case report. Pediatr Dent 1991; 13:236-7.

24. Mader CL. Talon cusp. J Am Dent Assoc 1981; 103: 244-6.

25. Shey Z, Eytal R. Clinical management of an unusual case of dense evaginatus in maxillary central incisor. J Am Dent Assoc 1983; 106: 346-8.

26. Al-Omari MAO, Hattab FN, Darwazeh AMG, Dummer PMH. Clinical problems associated with unusual cases of talon cusp. IntEndod J 1999; 21:183-190.

27. Ferres-Padro E, Prats-Armengol J, Ferres-Amat E. A descriptive study of 113 unerupted supernumerary teeth in 79 pediatric patients in Barcelona. Studies 2009;14(3):46-52.

28. Refoua Y, ArshadM. An unusual case of Bilateral Maxillary and MandibularSupernumerary Teeth. Journal of Dentistry Of Tehran University Of Medical Sciences 2006;3(3):140-2.

29. Arathi R, Ashwini R. Supernumerary teeth: A case report. Journal of Indian Society of Pedodontics and Preventive Dentistry2005; 23(2):103.

30. Ramsaran A, Barclay S, ScipioE, Ogunsalu C. Non-syndromal multiple buried supernumerary teeth: report of two cases from the English-speaking Caribbean and a review of the literature. West Indian Medical Journal 2005;54:334-6.

31. Fleming P, Xavier G, DiBiase A, Cobourne M. Revisiting the supernumerary: the epidermiological and molecular basis of extra teeth. British dental journal 2010; 208(1):25

32. Tereza G, Carrara C, COSTA B. Tooth Abnormalities of Number andPosition in the Permanent Dentition of patient with Complete Bilateral Cleft Lip and Palate. The cleft Palate-Craniofacial Journal 2009.

33. Koc A, Onur S, Ergun M, Percin E. Supernumerary marker chromosome 15 in a male with azoospermia and open bite deformity. Asian journal of andrology 2009.

34. Sedano $\mathrm{H}$ et al. Multiple dens invaginatus, mulberry molar and conical teeth. Case report and genetic considerations. Medicina oral, pathology oral buccal 2009;14(2):E69.

35. ZHANG Y, ZhiC, Yi Qiang S, Chao L, Chen Y. Making a tooth:growth factors, transcription factors, and stem cells. Cell Research 2005; 15(5):301-16

36. Ten Cate A, Dale A. Oral histology: development, structure and function. $4^{\text {th }}$ ed. St. Louis:Mosby; 1994.

37. Thesleff I. Tooth morphogenesis. Advances in Dental Research 1995; 9:12 


\section{CASE REPORT}

\section{TABLE \& PHOTOGRAPHS:}

\begin{tabular}{|c|c|}
\hline Classification Based On Form & Classification Based On Position \\
\hline Conical & Mesiodens \\
\hline Tuberculate & Paramolar \\
\hline Supplemental & Distomolar \\
\hline Odontome & Parapremolar \\
\hline & Table 1 \\
\hline
\end{tabular}

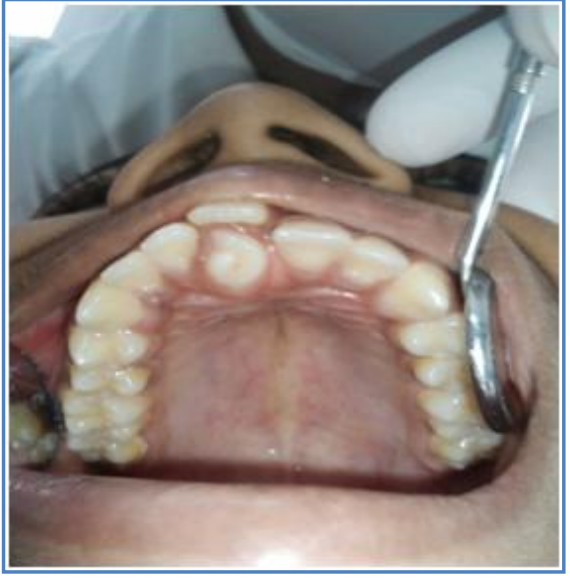

Fig. 1:A talon cusp on a right maxillary supernumerary tooth resulting in slight labial position of the right central incisor and midline diastema.

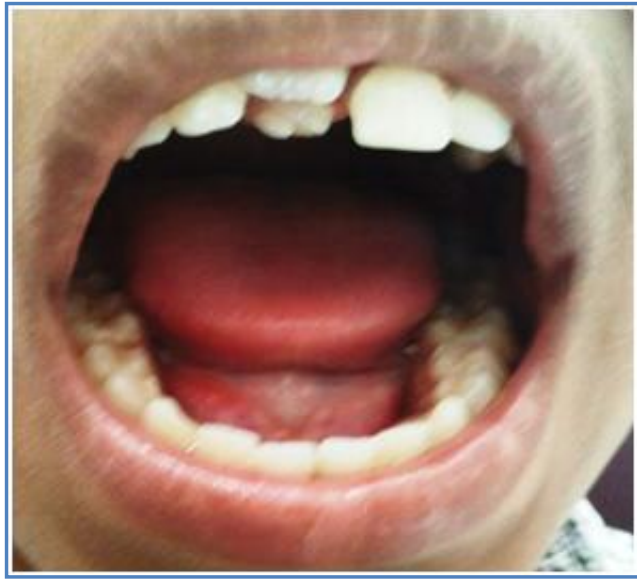

Fig. 2:A talon cusp on right maxillary supernumerary tooth and presence of one extra lateral incisor on the same side.

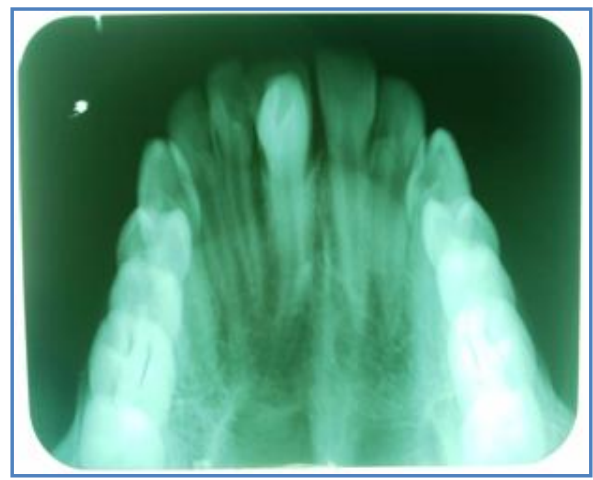

Fig. 3:Periapical radiograph shows a V-shapedtalon cusp of enamel and dentin with pulp tissueon supernumerary tooth and one extra lateralincisor on the same side.The talon cusp extendsfrom the cemento-enamel junction to the incisal edge. 


\section{CASE REPORT}

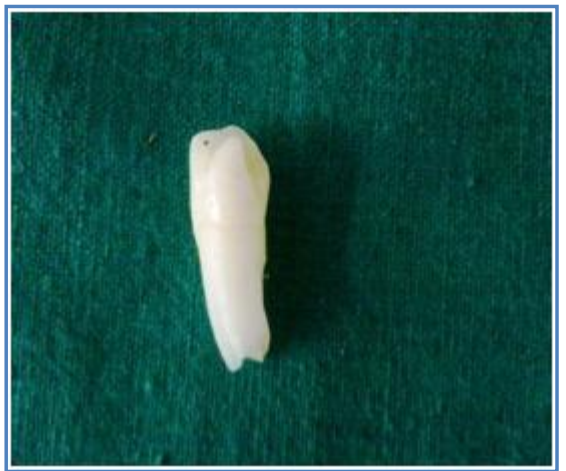

Fig. 4:Extracted supernumerary tooth. Talon cusp on the palatal surface of the supernumerary tooth, extending from the cementoenamel junction to the incisal edge.

\section{AUTHORS:}

1. Deepa Hugar

2. SangmeshwarSajjanshetty

3. SantoshHugar

4. SrideviTamagond

\section{PARTICULARS OF CONTRIBUTORS:}

1. Senior Lecturer, Department of Oral pathology \& Microbiology, H.K.E. Society's, S. Nijalingappa Institute of Dental Science \& Research, Gulbarga, Karnataka, India.

2. Senior lecturer Department of Pedodontics and preventive dentistry H.K.E. Society's. S. Nijalingappa Institute of Dental Science \& Research, Gulbarga, Karnataka, India

3. Reader, Department of Conservative \& Endodontics, Bharatiya Vidyapeeth Dental College and Hospital, Sangli, Maharastra, India.
4. Senior lecturer Department of Pedodontics and preventive dentistry Bhartiya Vidyapeeth Dental College and Hospital, Sangli, Maharastra, India.

\section{NAME ADRRESS EMAIL ID OF THE CORRESPONDING AUTHOR:}

Dr. Deepa Hugar

C/o Dr.Sangameshwar Sajjanshetty

Pl.No19,Vasanth Nagar

Gulbarga-585103

E-mail; deepahugar12@yahoo.co.in

Date of Submission: 27/11/2013.

Date of Peer Review: 28/11/2013.

Date of Acceptance: 04/12/2013.

Date of Publishing: 11/12/2013 